\title{
An Article Review on Islamic Derivatives: Theory and Practice, Global Islamic Finance Report (GIFR) 2010
}

\author{
Herbi Arfah Renaldi Sumitro ${ }^{1}$
}

\begin{abstract}
The purpose of the study is to provide a systematically structured article review on a report chapter entitled Islamic Derivatives: Theory and Practice. There is a global trend on the demand of Islamic Capital Market advancement from theoretical paradigm to practical innovative shariah compliant diversification products, therefore, a brief academic review shall be one of the triggering variables to promote more enhanced development of derivatives products which are in accordance with principles of modern practices without excluding the cornerstone of shariah requirements. The review is based on key findings discussion that programmed to envision the general and the specific (significant) terms found in the article. This includes scholarly opinions, fatwas, standards, and guidelines as well as opinion on the subject matters. The study has shown that there is a call for further study to collect global experiences as well as perspectives on Islamic derivatives development.
\end{abstract}

Keywords: Islamic Finance, Islamic Capital Markets, Islamic Derivatives, Forwards, Futures, Options, Swaps, Murabaha, Wa'ad, Arbun and Salam.

\footnotetext{
${ }^{1}$ Master in Islamic Finance Practice (Cand.), International Centre for Education in Islamic Finance, The Global University of Islamic Finance. Contact email: herbisumitro@gmail.com
} 


\section{Introduction}

\section{Summary of The Article}

The material studied in this review mainly focus on systematic approach towards the building the ground of Islamic Capital Markets instruments, in this regard is Islamic derivatives. There four basic application of conventional derivatives known to actively instrumental in academic and industry practices, namely; forwards models, futures, options and swaps contractual instruments that are formed either bilateral OTC models or trading and risk management, speculation as well as arbitrage.

Afterwards, the discussion entails shariah-based instruments developed to meet the demand of market which scholars are convergence in general on the idea of Islamic derivatives on the ground of maslaha (public interest) and ibaha (permissible) with divergence variable to jurisdictions and schools of fiqh (Islamic law).

There two main discoveries in which the article specifically highlighted: liquidity and credibility issues in products or instruments of Islamic derivatives. As such disadvantages, the growing of Islamic finance is significant for few decades in key jurisdictions such as Malaysia and Middle East countries. In these two main actors in Islamic derivatives development, we can generally expect key instruments are instrumental. The structures have been mainly focusing on the utilisation of murabaha, $w a ' a d$, arbun and salam. The products or instruments are discussed based on structures and cash-flows (both conventional and shariah ones) with special reference to industrial usages.

Intended to be legitimately approved in Islamic world and practice of modern mu'amalah, Islamic derivatives have been growing in a slow yet careful path in products variation. The products range from term and reverse murabaha-based of cross-currency swap used by Citigroup (hedging by DIB) to profit rate swap with additional series of secondary murabaha performed by SC Saadiq to wa'ad-structured FX Option introduced by GFH to double-wa'ad of total return swap prepared by Deutsche Bank 
An Article Review on Islamic Derivatives: Theory and Practice, Global Islamic 116 Finance Report (GIFR) 2010

to arbun-structured short selling exercised by Barclays Capital and salam-based short selling in Newedge products.

In last remark, the article emphasized again the issue of divergence in Islamic Finance products is substantially derived from lack of centralisation, harmonisation, and uniformity of regulatory regime. The need for innovation is also proposed along with capturing new challenges and growing markets potential.

\section{Key Findings}

The article designed as pre-existing theoretical and practical experiences of Islamic derivatives instruments. Globally by referring to Jobst \& Sole (2009) and (Malkawi, 2014), these are the known list of contracts to formulate Islamic derivatives instruments; salam, mu'ajjal, bithaman ajil, istisna, tawarruq, muqassah, kafalah and khiyar shart. The following is the main idea of underlying contracts used in Islamic Derivatives where the text is envisioned:

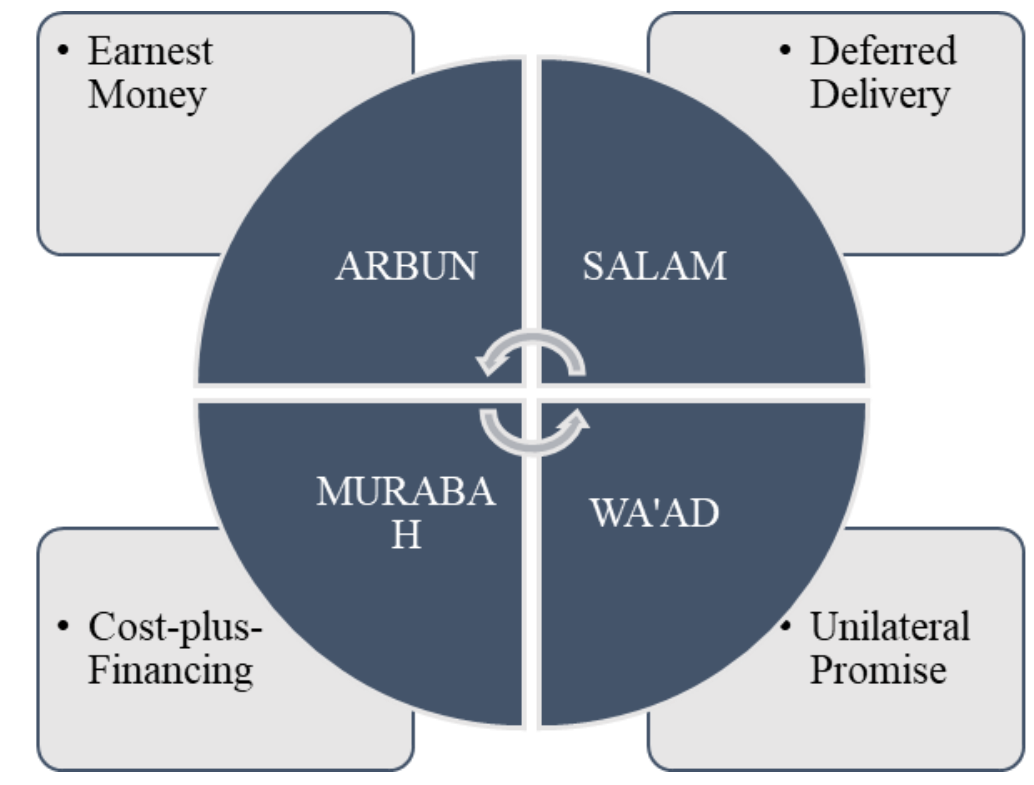

Diagram 1. Islamic Contracts in Islamic Derivatives. 
Source: GIFR (2010), author's visualisation

Where the primary sources of Islamic Derivatives knowledge were still limited during the report was disseminated, the coverage was comparatively comprehensive summary during that time. This can be seen to the structure presented in the report where main products were discussed in brief with both conventional and shariah ideal structures and presentation of some notable examples from each product. The discussion is mainly detailed on the application of Islamic contracts to structure derivatives instruments such as forwards, futures, options, and swaps. These types of instruments are engineered with embedded shariah-compliance contracts to meet industrial and market need. The following are the summary of key findings in relation to Islamic derivatives practices.
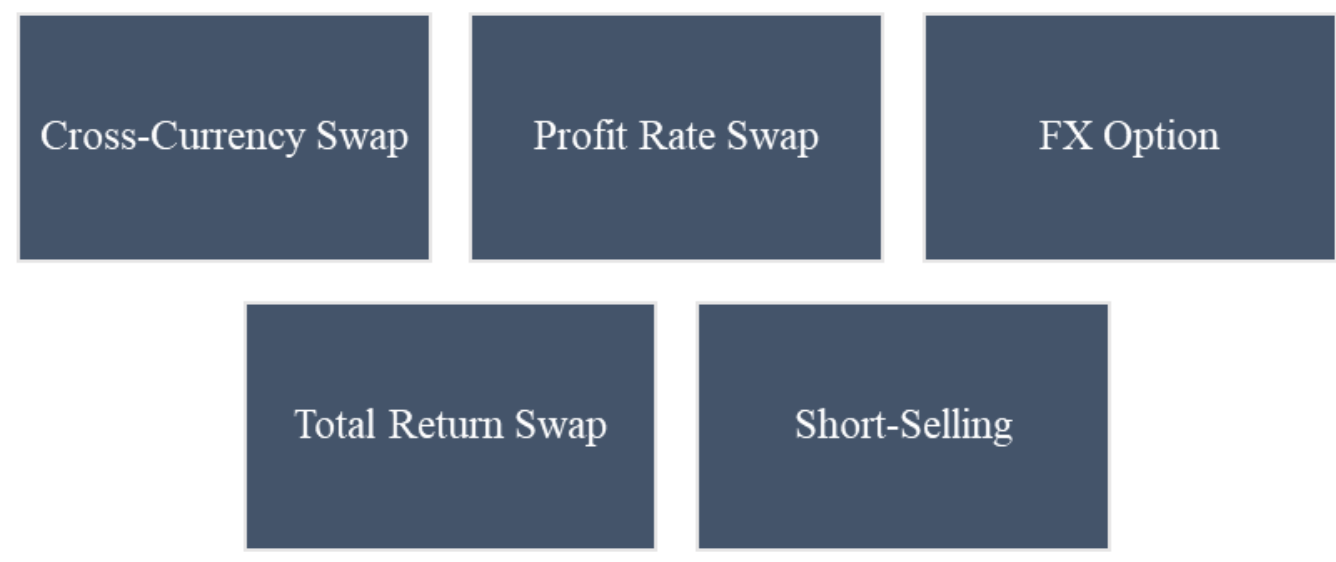

Diagram 2. Islamic Derivatives Instruments

Source: GIFR (2010), author's visualisation

\section{Materials and Methods}


An Article Review on Islamic Derivatives: Theory and Practice, Global Islamic 118 Finance Report (GIFR) 2010

The article review will accommodate a wide range of academic exploration in theoretical manners as well practical and industrial models. The study is specified on academic articles which covered basic development of Islamic derivatives theoretical landscape to more current paradigm in the industrial knowledge and best practices. The methods used are literature reviews from academically approved journals and credible market data resources.

\section{Reviews, Analysis and Discussion}

We have summarized our key findings on the report with regard to Islamic derivatives, hence we are going to systematically enhanced the findings by analytical discussions from foundational theories and their development to encompassing contemporary juristic opinions and standings from internationally acknowledged individuals and standards settings.

Even though there were limited types of conservative instruments presented in the report, a significant note to the effort to simplify most used derivatives instruments escalated neatly. Evidently, INCEIF (2012a) has shown academically reference towards common features and instruments in derivatives markets. A contract base on forward contracts with lockedin price for both parties, a standardised forward contracts base on futures contracts, a flexible and engineered-friendly contract based on options, and swaps contracts features OTC model of contracts.

While most literature focusing on the readily embedded Islamic financial contracts instruments in Islamic Capital Market; salam, istisna, istijrar and joala (INCEIF, 2012b), the report clearly focusing in the instrumental elements of Islamic derivatives. This is imperative to note that development of idea to search derivatives features in Islamic finance classical contracts has been tremendously significant where comprehensively programmed in the early academic literature works in some talent development institutions. Impressively many has agreed on the ground elements of derivatives salam, istisna and joala while few has shown disagreement 
(INCEIF, 2012b; Hisham \& Jaffar, 2014; Munir \& Ryan, 2016; Sakti et al., 2016).

Formulated to bring comprehensive building blocks of derivatives instruments in Islamic Capital Market world, the report has been presenting a set of contracts that are most prominent especially in structuring the Islamic derivatives. As murabaha-based contracts are increasingly dominant in general Islamic banking and finance products structuring, the idea of cost-plus financing was undeniable in developing derivatives with shariah compliant tenets embedded in the models. According to Hisham \& Jaffar (2014) the concept of murabaha has been used to synthetically combined with futures contracts in derivatives instruments as not few were discouraging its utilisation and encourage more innovative techniques (Forster-jones, 2012). The further optimalisation of murabaha concept in shariah models of derivatives is mostly because there is a great opportunity to develop murabaha-based contracts to more enhanced products with the combination of wa'ad and series of murabaha (Hisham \& Jaffar, 2014; Meo et al., 2020; Munir et al., 2016; Rahman \& Ramli, 2015).

It is most likely to see $w a^{\prime} a d$ as complementary yet significant contractual arrangement of Islamic finance instruments. As of murabaha that is mostly crafted into swaps models in Islamic derivatives instruments, wa' $a d$ is an essential contract to compliment not only murabaha but other shariah-approved derivatives like total return swap and FX options. The report has suggested a conclusion where wa'ad in its development was understood interrelated with murabaha scheme whereby its later potential is extended to utilise such contract with international approval. Bacha (2012) explained wa'ad is understood to be unilaterally driven promise in exchange of counter-value of fee. In a nutshell, in a study by (Geçmişi, 2020) summarised that a wa'ad contract arrangement has diverge scholars on whether it is morally or legally enforceable or not in the court of law. There is no further emphasis on wa'ad principles in the report, however in-depth categories were discussed on application of wa'ad in swap, options and forwards (Bacha, 2012). It facilitates basic management for currency risk (Bacha, 2013). Furthermore, critics have been extensively relevant in our further discussion as academia has done (Meo et al., 2020). 
An Article Review on Islamic Derivatives: Theory and Practice, Global Islamic 120 Finance Report (GIFR) 2010

Arbun is an Arabic term to signifies earnest money or explains deposit in modern context. It is a classical type in Islamic contracts that has been vital in developing Islamic products and structuring. Its basic model and features have been associated with options in conventional derivatives (Malkawi, 2014). The text confirmed the association whereby many has been sceptical to accept arbun as an authorised Islamic contract so as khiyar shart (Sakti et al., 2016). Rizvi et al. (2014) explained that arbun is differ from conventional arrangement in the matter of pricing where regular call option the price is excluded from actual price. It is an embedded element in arbun to facilitate and to compensate risk and as an incentive to perform the contracts (Malkawi, 2014). The concept of $a r$ bun in later discussion is relevant to approve options instruments in shariah-compliant derivatives, in short, the concept at least favourable to back as collateral and promoting risk sharing (Geçmişi, 2020).

According to Bacha (2012), Sakti et al. (2016) and Meo et al. (2020) salam contracts is prominent pattern on the foundational blocks of Islamic derivatives development. This is true where it is seen as an exceptional contract introduced since the Prophet's time. In the report salam is essential to formulate contracts seeking for working capital such as in short selling. Bacha (2012) believed the provision and the precedence in salam contracts have increase its smooth introduction into promoting working capital financing. Even though its seen to be forwards-like instruments, the text claimed to be similar to forwards contracts with specifically referred as an equivalent by Bacha (2013), salam was argued by Mufti Taqi Utsmani in Sakti et al. (2016) as different with forwards contracts, therefore he suggested forwards to be unacceptable. However, in the context of distinguishing feature from conventional future contracts, salam is unique with full prepayment (Rizvi et al., 2014), in which is substantially essential for further basis development as an Islamic derivatives signature instruments.

\section{Islamic Cross Currency Swaps (ICCS)}

Structurally, a conventional swaps arrangement is not shariah compliant due to elements of interest, excessive uncertainty and gambling are exist- 
ed. The article, as many also proposed, there is a potential shariah approved instruments using swaps with modification of murabaha inculcated into the contracts. This would allow instrumental cash-flow mimicking the conventional one. The structure however, in compared to commercial used in CIMB Islamic (2020) and explained in Dusuki (2012), is shortly variative whereby types of contracts are proposed, namely; commodity murabaha, commodity musawamah, wa'ad and bai' sarf. Furthermore, any rational justifications are also become the article's shortcomings in compared to other some literatures (Jobst \& Sole, 2009; Malkawi, 2014; Mohamad et al., 2011; Nik Zati Hulwani \& Nik Maheran, 2018; Nordin et al., 2017; Rahman \& Ramli, 2015; Ramasamy et al., 2011; Zahan \& Kenett, 2012).

It is a premature judgement to consider which forms are more shariah compliant in cross currency swap arrangements. The swaps model in Islamic derivatives, particularly this Islamic Cross Currency Swaps, started to grab attention and to some extent controversies when the use is only to exchange money which is not recognised under Islamic tenets as a tradable items (Forster-jones, 2012). Either the reviewed article or CIMB Islamic (2020) are in agreement where the presented structures utilised both fixed and float rate, in which consistent with the idea to minimize interest rate risk (Obiyathullah Ismath Bacha, 2012a) and the element of gharar. This is possible also, in addition to fixed-float rates, with the usage of fixed-fixed rates arrangements with signifies minimalization of uncertainty (Dusuki, 2012). To this point, the report is needed to emphasise on not only murabaha structures presentation but also bringing the significance of bai' sarf as prominent part in the arrangements.

\section{Profit Rate Swaps}

Islamic Profit Rate Swaps (IPRS), shortly Profit Rate Swaps, delivered in the concept of murabaha with series of reverse murabaha. The report provided similar concept to what is exercised in ICCS. According to CIMB Islamic (2020), IPRS is beneficial to the extent that it provides such facilities in hedge accounting measurement and is highly effective and efficiently liquid. As an invention to meet market demand on Islamic 
An Article Review on Islamic Derivatives: Theory and Practice, Global Islamic 122 Finance Report (GIFR) 2010

derivatives instruments, IPRS can facilitate a narrower interest rate risk as it fill the duration gap problem (Bacha, 2012). With inception of wa'ad in the IPRS, according to Rahman \& Ramli (2015), the maturity would be ensured and attained until the swaps expired. Yankson (2011) explicitly proposed there is a possible win-win contractual agreement in the IPRS as he referring to Al-Suweilim's non-zore-sum contracts idea on the principles of Islamic finance.

The range of issues in IPRS is also wide since it is not free from scholars and jurists' criticism. Early commentaries in Jobst \& Sole (2009) for the lack of legal standard and market practices uniformity were still relevant to date in which non-binding shariah precedent and approval process become majority concerns. It is hardly applicable for some jurisdiction to perform IPRS unless there is a great necessity or emergency (Zahan \& Kenett, 2012). Meo et al. (2020) and Nik Zati Hulwani \& Nik Maheran (2018) even directly claimed that IPRS has made many scholars uncomfortable that is mainly for the reason on unacceptable profit gained from a binding unilateral promise. Moreover, critics on ownership risk, Nik Zati Hulwani \& Nik Maheran (2018) claimed that the actual connection between metal contracts and metal stocks as the means within the arrangement is artificial, forced and not genuine. Sakti et al. (2016) confirmed that another non-shariah compliant is found under the arrangement of IPRS which is kali' bil-kali or the sale of one debt for another.

\section{FX Options}

I do personally agree with the report explanation on the options requirements under Islamic principles. There is no options without genuine sale or purchase because the underlying contract used in Islamic options is $w a ' a d$, and simple way a complementary contracts to facilitate the hedging of a real trading of assets avoiding excessive gharar and gambling. As for a regular conventional option there will be significant shariah disagreement in the concern of ownership, existence, speculations, gambling, delivery and receipt (Sakti et al., 2016). By referring to our earlier discussion on $w a$ 'ad and the issues attributed to it, it is reasonable to see the controversies emerged in the development of foreign exchange op- 
tions. In the early 1990s, the OIC Islamic Fiqh Academy in Rahman \& Ramli (2015) has resolved the impermissibility of options contracts due to hazy basis of the object of such contract.

An Islamic FX Options is structured as a replication of conventional options for foreign exchange currency (Bacha, 2012b). The report summarized the concept of FX Options based wa'ad is solely resemble the cash flows in currency call and put options. The IFIs would benefit from fee paid upfront against the wa'ad contracts which is confirmed to be generally disputable by many according to Sakti et al. (2016). The basis to put FX Option based on $w a$ 'ad or specifically wa'dan (a unilateral promise) contracts has made only under the necessity reasoning (Ahmad et al., 2014), which is in the general has relatively weak legal precedent. The need to put more effort on the foundation of wa'ad-based FX Options necessitates its shariah ground and market growing demands.

\section{Total Return Swaps}

In reviewing the report, there are few contextual and factual literatures concerning the development of Islamic Total Return Swap. In a working paper published by IFSB (Alam, 2019) showed in nearly 10 years' time the concept has not been changed much as originally presented in the text. Conventional total return swaps is considerable and potential mechanism in which Islamic derivatives must seek further advancement by reevaluating the basis used in the structure. Double wa'ad structure has been prominent under total return swap that meets shariah requirements. The wa'ad in total return swaps mechanism in fact was introduced by Deutsche Bank and approved by prominent scholars in Dar Al Istithmar.

The concept has gained much attention by investors in such a way that it can facilitate and reduce some cost without owning the referred original assets. In another way, it allows the holders or investors to gain such potential returns in specific basket in which generates by shariah-approved assets and swap the gain returns with another basket. Furthermore, products development using the total return swaps could possibly shariah compliance with the concept of ji'alah or khiyar shart (Munir et al., 
An Article Review on Islamic Derivatives: Theory and Practice, Global Islamic 124 Finance Report (GIFR) 2010

2016), however due to lack of innovation, the literature on the concept are rarely available.

\section{Short Selling}

The uniqueness of salam contracts is found when the structure is used to form short selling as an Islamic derivatives product. Salam is unique base on its availability since the beginning of Islamic civilization. In the report provided there has been two types of Islamic short selling, namely, based on arbun and based on salam. The conventional one typically constructed based on borrowed stocks or shares, in other way not on the ownership of the seller. This is indeed not accepted in shariah settings of mu'amalat. Both concepts arbun and salam are instrumental in Islamic derivatives especially this short selling arrangement and would be accepted only and if only cover and resume the ownership physically or constructively, some are even strictest. Arbun is still controversies by many jurisdictions for Islamic derivatives instrument and only accepted by referring to Hanafi mazhab.

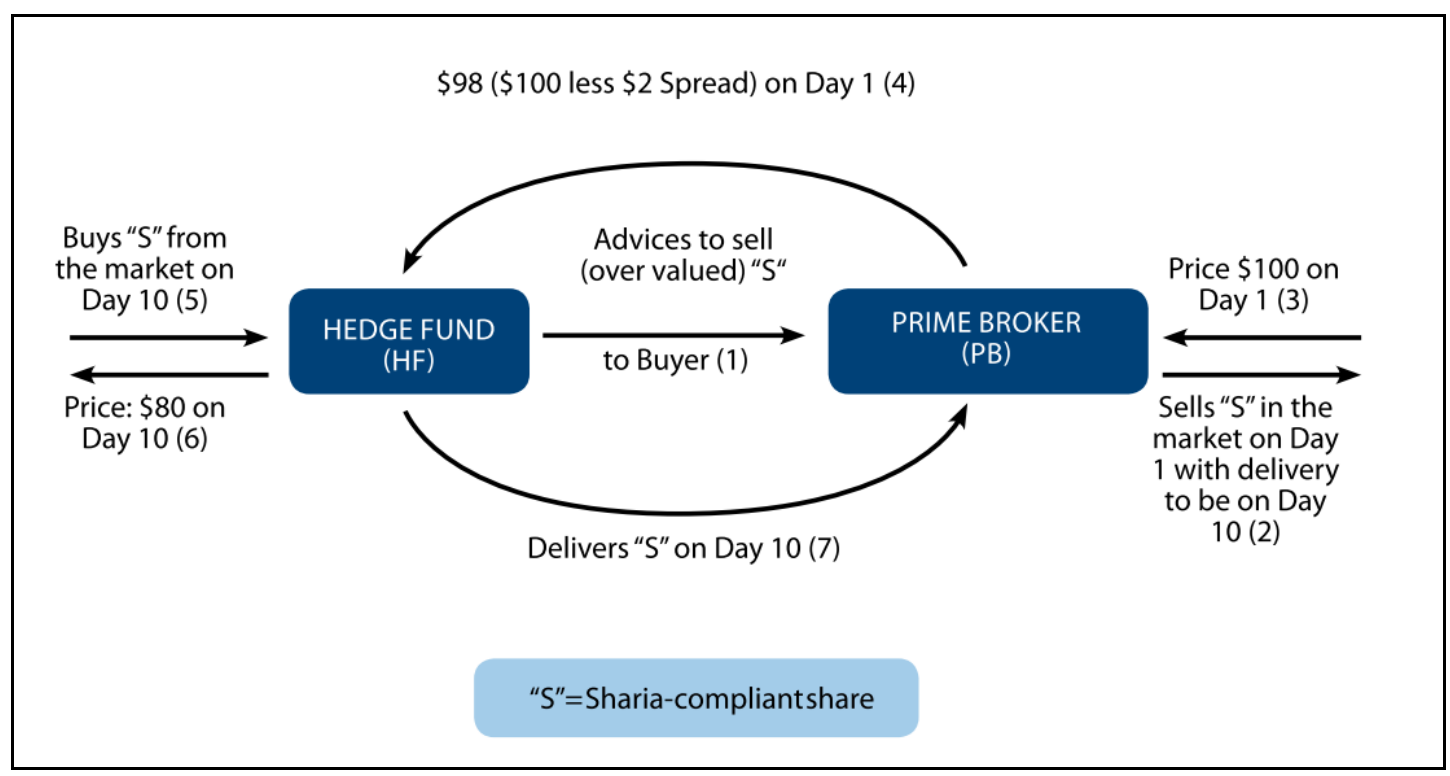


Salam in Short Selling, Source: GIFR 2010

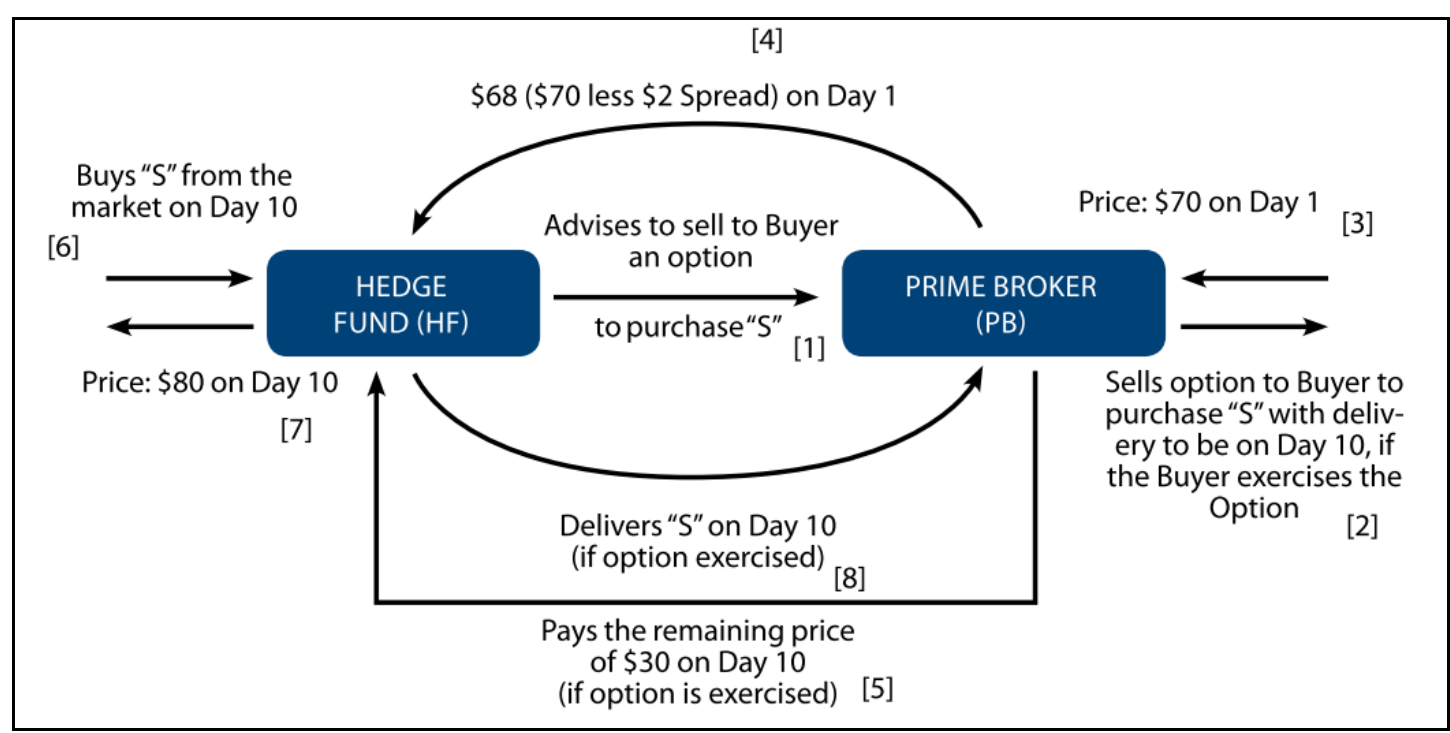

Arbun in Short Selling, Source: GIFR 2010 
An Article Review on Islamic Derivatives: Theory and Practice, Global Islamic 126 Finance Report (GIFR) 2010

\section{Conclusion}

Islamic derivatives are primarily developed to inject the gap in risk management for Islamic financial institutions. The products in which risks must be managed theoretically are encouraged by shariah due to the concept of maqasid shariah. Global Islamic Finance Report 2010 has specifically condensed the academic literatures and industrial progress where Islamic derivatives instruments and products are found. The four basic shariah-based contracts proposed in the report with their conceptual practice in the form if forwards, futures, options and swaps.

From the brief article review above it is confirmed that global standardization is an urgent call for Islamic Capital Market to thrive. The formats in such derivatives instruments and products are essentially more complex and need systematic in-depth research and development efforts. It is an opportunity to collect global effort to strengthen products diversification by harmonising the dissenting opinions, understanding market and industry demands, recognizing regulatory requirements and supporting initial structuring of Islamic products such as Islamic banking institutions.

The regulatory challenges may rise out our concerns since the different socioeconomic and political contours of Islamic world contribute significantly to development process. Some jurisdictions are really putting their best support and appreciation towards the dissemination of new and innovative products in derivatives world. This shall trigger our contribution to fill the long gap in this section of Islamic Finance, therefore, to briefly summarise the context, given the current potential and leverage in Islamic Finance, more prominent and actual financial engineering in derivatives must be prioritised. Challenging recent graduates and practitioners to bravely collaborate, contribute, enhance, try and error the full potential of Islamic derivatives. 


\section{References}

Ahmad, A. A., Yaacob, S. E., \& Mat Zain, M. N. (2014). The Use of wa'Dan in Islamic Contract FX Forward: Weighting between Maslahah and Mafsadah. Asian Social Science, 10(22), 332-342. https://doi.org/10.5539/ass.v10n22p332

Alam, N. (2019). IFSB WORKING PAPER SERIES WP-14/12/2019 (Issue December). IFSB.

Bacha, Obiyathulla Ismath. (2013). Risk management, derivatives and shariah compliance. AIP Conference Proceedings, 1522(January 2013), 17-28. https://doi.org/10.1063/1.4801099

Bacha, Obiyathullah Ismath. (2012a). Shariah Compliant Derivative Instruments. In N. Kerchene (Ed.), IB1006: Islamic Capital Markets Enhanced Edition of CIFP Module (2nd ed., pp. 1-20). INCEIF.

Bacha, Obiyathullah Ismath. (2012b). Unit 11 Exchange Rates amd the Foreign Exchange Market. In IB1006: Islamic Capital Markets Enhanced Edition of CIFP Module (2nd ed., pp. 1-39). INCEIF.

Dusuki, A. W. (2012). Principles and Application of Risk Management and Hedging Instruments in Islamic Finance. 1-30. www.iefpedia.com/english/wp-content/uploads/2012/07/Asyraf.pdf

Forster-jones, M. (2012). The evolution of Islamic derivatives. February, 25-26.

Geçmişi, M. (2020). MALEZYA ' NIN YAPILANDIRILMŞ ÜRÜNLERINDE ISLAMI GÖMÜLÜ OPSIYONLAR: SORUNLAR VE ZORLUKLAR. 6(1), 103-124.

Hisham, A. F. B., \& Jaffar, M. M. (2014). A review on mathematical methods of conventional and Islamic derivatives. AIP Conference Proceedings, 1635(December https://doi.org/10.1063/1.4903600

2014), 308-315. 
An Article Review on Islamic Derivatives: Theory and Practice, Global Islamic 128 Finance Report (GIFR) 2010

Islamic, C. (2020). Islamic Derivatives Instruments Section 2 Islamic Foreign Exchange ( FX) Derivative Solutions. March, 1-27.

Jobst, A. A., \& Sole, J. (2009). The Governance of Derivatives in Islamic Finance. Jiblr, 24(11), 556-565.

Malkawi, B. H. (2014). Financial derivatives between western legal tradition and islamic finance: A comparative approach. Journal of Banking Regulation, 15(1), 41-55. https://doi.org/10.1057/jbr.2012.18

Meo, M. S., Durani, F., Kouser, R., Haris, M., \& Iram, T. (2020). Modern derivatives in Islamic perspectives in Pakistan: Shari'ah issues on current Islamic derivative practices. Journal of Public Affairs, September. https://doi.org/10.1002/pa.2454

Mohamad, S., Ahmad, A., \& Shahimi, S. (2011). Innovative Islamic Hedging Products: Application of Wa'd in Malaysian Banks. In Capital Markets Review (Vol. 19, Issue 1, pp. 33-51).

Munir, S., Ryan, B., Hussainey, K., \& Majeed, muhammad imran. (2016). Practitioners 'Perceptions of Islamic Derivatives vis-à-vis Conventional Derivatives in Pakistan. European Journal of Social Sciences, 51(3), 201-219.

Nik Zati Hulwani, N. I., \& Nik Maheran, N. M. (2018). Explicit Derivative for Islamic Hedging: A Strategy for Reconsideration. E-Proceedings of the Global Conference on Islamic Economics and Finance 2018, October, 149-157.

Nordin, N., Daud, N., Mohammad, M., Jusoh, H., Jusoh, M. S., \& Ismail, F. (2017). Commodity Derivatives: Shariah Alternatives in Risk Management? International Journal of Academic Research in Business and Social Sciences, 7(4), 232-246. https://doi.org/10.6007/ijarbss/v7i4/2802

Rahman, A. A., \& Ramli, R. (2015). Islamic Cross Currency Swap (ICCS): hedging against currency fluctuations. Emerald Emerging Markets Case Studies, 5(4), 1-12. https://doi.org/10.1108/EEMCS-09-20140215 
Ramasamy, R., Munusamy, S., \& Helmi, M. H. M. (2011). Basic Pricing Methodology For Islamic Profit Rate Swap. Global Journal of Management and Business Research, 11(5), 37-48.

Rizvi, S. A. R., Arshad, S., \& Lahsasna, A. (2014). Derivatives in Islamic finance: the need and mechanisms available. International Journal of $\begin{array}{llll}\text { Financial Services } & \text { Management, } & \text { 7(3/4), } & 177 .\end{array}$ https://doi.org/10.1504/ijfsm.2014.065572

Sakti, M. R. P., Syahid, A., Tareq, M. A., \& Mohd Mahdzir, A. (2016). Shari'ah issues, challenges, and prospects for Islamic derivatives: a qualitative study. Qualitative Research in Financial Markets, 8(2), 168190. https://doi.org/10.1108/QRFM-06-2015-0024

Yankson, S. (2011). Derivatives in Islamic Finance - A Case for Profit Rate Swaps. Journal of Islamic Economics, Banking and Finance, 7(1), 39-56.

Zahan, M., \& Kenett, R. S. (2012). Hedging Instruments in Conventional and Islamic Finance. Electronic Journal of Applied Statistical Analysis: Decision Support Systems and Services Evaluation EJASA, 3(1), 59-74. https://doi.org/10.1285/i2037-3627v3n1p1

INCEIF. (2012a). IB1006: Islamic Capital Markets Enhanced Edition of CIFP Module 2012. Unit 9 Derivatives Instruments: Products and Applications. Kuala Lumpur: INCEIF

INCEIF. (2012b). IB1006: Islamic Capital Markets Enhanced Edition of CIFP Module 2012. Unit 10 Shariah Compliant Derivatives Instruments. Kuala Lumpur: INCEIF

INCEIF. (2012c). IB1006: Islamic Capital Markets Enhanced Edition of CIFP Module 2012. Unit 11 Exchange Rate and the Foreign Exchange Market. Kuala Lumpur: INCEIF 